\title{
Endoparasites of Northern Sharp-Tailed Grouse, Tympanuchus phasianellus phasianellus, as Related to Age and Position on the Lek
}

\author{
LEONARD J.S. TSUJI ${ }^{1}$ and GERARDO DeIULIIS ${ }^{2}$
}

(Received 31 January 2002; accepted in revised form 2 December 2002)

\begin{abstract}
The only indication of endoparasites found in male sharp-tailed grouse collected during the breeding season from the western James Bay region of northern Ontario, Canada, were nematode eggs of an unknown species. Nematode egg loads of male sharp-tailed grouse that occupied central territories on leks (mating areas) were not significantly different from those of birds in peripheral territories, nor were they different between adult males and yearlings. Future studies of endoparasites in northern sharp-tailed grouse should consider nematodes, which have been shown to be important to survivorship of other grouse species.
\end{abstract}

Key words: sharp-tailed grouse, Tympanuchus phasianellus phasianellus, endoparasites, James Bay

RÉSUMÉ. Des œufs de nématodes provenant d'une espèce inconnue constituaient le seul indice de la présence d'endoparasites chez des mâles du tétras à queue fine prélevés durant la saison de reproduction dans la partie ouest de la baie James, au nord de l'Ontario (Canada). Il n'y avait pas de différence significative entre la biocontamination par les œufs de nématodes du mâle du tétras à queue fine occupant les zones au centre des leks (arènes de pariade) et celle des oiseaux occupant les parties périphériques, ni de différence notable entre les mâles adultes et ceux d'un an. De futures études menées sur les endoparasites du tétras à queue fine des régions nordiques devraient se pencher sur les nématodes, vu leur importance attestée pour la survie des autres espèces de tétras.

Mots clés: tétras à queue fine, Tympanuchus phasianellus phasianellus, endoparasites, baie James

Traduit pour la revue Arctic par Nésida Loyer.

\section{INTRODUCTION}

A lek can be defined as an area where males of a species establish territories, forming a cluster that females visit for the sole purpose of mating (Tsuji et al., 2001). Recently, it has been shown for the northern sharp-tailed grouse, Tympanuchus phasianellus phasianellus, that males occupying central territories on leks were in better body condition than their peripheral counterparts (Tsuji et al., 1994). Adult males were also more likely to hold a central position (Tsuji et al., 1994). Occupancy of a central territory on a lek has typically been related to preferred mating status in the sharp-tailed grouse (Kermott, 1982); that is, males in the central territories perform a disproportionate number of copulations compared to individuals on the periphery of the lek. Further, a bird's ability to defend a territory on a lek has been shown in grouse to be related to body condition, or the ability to maintain body condition, or both (Hupp and Braun, 1989), while endoparasite loads have been reported to have a negative effect on body condition (Wetmore, 1939; Hoglund et al., 1992). Thus, endoparasite loads may be related to the mating success of an individual.

The transmission avoidance hypothesis argues that females may avoid sickly individuals, preferring to mate with males who have traits associated with good health, such as large size (Loehle, 1997). In the lek-breeding sage grouse (Centrocercus urophasianus), Gibson (1990) reported that no measure of mating success was significantly related to a decrease in endoparasite load (Haemoproteus spp.) among adult males. By contrast, Hoglund et al. (1992) found that the most successful males on black grouse (Tetrao tetrix) leks were less often infected by Leucocytozoon spp. than other males. Similarly, Johnson and Boyce (1991) showed that the prevalence of Plasmodium pediocetii was less (but not significantly) for breeding male sage grouse. In another study investigating mate choice in sage grouse (Spurrier et al., 1991), half the males in an experimental group were treated with the antibiotic oxytetracycline (to reduce parasite load) while the other half acted as controls (i.e., they did not receive oxytetracycline for three months prior to the trials). It was found in this experiment that females chose treated males significantly more often than control males (Spurrier et al., 1991). However, a methodological problem exists in that mate-choice experiment, since it was never established clinically that the male individuals used suffered initially from any type of pathosis. Furthermore, oxytetracycline, a broad-spectrum antibiotic, affects a wide range of gramnegative and gram-positive organisms, as well as a large

\footnotetext{
${ }^{1}$ Department of Environment and Resource Studies, University of Waterloo, Waterloo, Ontario N2L 3G1, Canada; ljtsuji@ fes.uwaterloo.ca

${ }^{2}$ Department of Zoology, University of Toronto, Toronto, Ontario M5S 1A1, Canada

(C) The Arctic Institute of North America
} 
variety of other microorganisms (Krogh, 1991). Thus, oxytetracycline can affect an individual's behaviour by profoundly modifying normal bacterial flora so that usually nonpathogenic microorganisms become pathogenic after removal of the balancing effect of the normal flora (Finland, 1973). The main point is that even though treated males in the sage grouse experiment were chosen by females more often than the controls (Spurrier et al., 1991), it cannot be assumed that these treated males were chosen because they had lower parasite loads. The reason for mate choice in this experiment is unclear and may be related not to the primary effect of the antibiotic, but to one of the numerous associated side effects. Whether parasite loads affect mating success in grouse is still unclear. In this paper, we examine male northern sharp-tailed grouse and relate endoparasite loads to age and territorial position on the lek.

\section{MATERIALS AND METHODS}

\section{Study Area and Sample Population}

Study sites were located in areas of muskeg on the western shore of James Bay, near Fort Albany, Ontario $\left(52^{\circ} 15^{\prime} \mathrm{N}, 81^{\circ} 35^{\prime} \mathrm{W}\right)$. Three main vegetation types have been described by Hanson (1953) for this region: blocks of various sizes containing stunted black spruce or stands of open grown tamarack; brushy areas on hummocky ground covered by moss and lichens; and water-logged areas of grasses and sedges that sometimes form floating mats in the numerous lakes and ponds. During the 1990-92 breeding seasons (last week of March to the third week of April), we observed male sharp-tailed grouse at six leks, each located less than $75 \mathrm{~km}$ from the others. In total, 52 grouse were observed for at least three consecutive days from 0530 to 0830 . Males were classified in the field as possessing either central or peripheral territories, following Tsuji et al. (1994). Individuals were aged (Ammann, 1944) after being harvested by Native Canadians for food.

\section{Hematozoa}

Blood films were prepared as described by Bennett (1970). All blood smears were examined for five minutes ( $\times 250, \times 400$ objectives) for the presence or absence of endoparasites of the genera Leucocytozoon, Trypanosoma, Microfilaria, Haemoproteus, and Plasmodium.

\section{Coccidia}

The left caecum was dissected free from the body cavity for a subsample of 26 individuals (from leks 1-4) and stored in $15 \%$ buffered formalin. Each caecum was subsequently partitioned into three parts (proximal, middle, and distal). A section of caecum from each part was embedded in paraffin and sectioned by microtome ( $7-10 \mu \mathrm{m}$ thick), and a representative ribbon of five sections (adhered by albumin to a slide) was stained with hematoxylin and eosin. Each slide was examined for five minutes $(\times 250$ objective) for the presence or absence of Coccidia gametes in the caecal epithelial lining.

Fecal samples were obtained from the distal portion of the intestinal tract for individuals from leks 5 and $6(\mathrm{n}=$ 26). Individual fecal samples were then placed in a $2 \%$ solution of potassium bichromate and left at room temperature for 72 hours with free access to air, before being sealed in their respective containers (Kheysin, 1972). Fecal samples were examined in wet mounts under a compound microscope $(\times 100, \times 400$ objectives $)$ for the presence or absence of coccidial oocysts (Chen and Desser, 1989).

\section{Nematodes}

The digestive tract of each individual (less the left caecum) was dissected free of the body cavity, and a direct search was made for Seurocyrnea colini and Heterakis gallinae, which have been reported in the gizzard and caecum, respectively, of sharp-tailed grouse (Morgan and Hamerstrom, 1941). The fecal wet mounts obtained from a subsample of 26 individuals from leks 5 and 6 (see Coccidia section) were examined for five minutes $(\times 100$ objective) for the presence or absence of nematode eggs. Samples were quantified by counting the number of eggs present in 10 fields ( $\times 400$ objective).

\section{Statistics}

Data for nematode egg loads (leks 5 and 6 ) were analyzed by Wilcoxon rank-sum tests $(\alpha=0.05)$ between central and peripheral males (one-tailed), and adults and yearlings (two-tailed).

\section{RESULTS}

No hematozoa were found in the 52 blood smears examined from male sharp-tailed grouse. Similarly, no Coccidia gametes were observed in the slides of caecal epithelium (leks $1-4, n=26$ ), nor were coccidial oocysts found in the fecal wet mounts (leks 5 and $6, \mathrm{n}=26$ ). Although direct examination of the gizzard and right caecum failed to reveal nematodes in any of 52 individuals, a subsample of 26 individuals from leks 5 and 6 harboured nematode eggs of an unknown species. All 26 fecal wet mounts contained these eggs, which were morphologically dissimilar to those of either $S$. colini or $H$. gallinae (Sloss, 1970). As hematozoa, Coccidia, and adult nematodes were absent from blood and gut tracts of individuals from leks 1 to 4 , further analysis was confined to the 26 males from leks 5 and 6 .

Seven individuals were yearlings occupying peripheral territories. Adults occupied both central $(\mathrm{n}=14)$ and peripheral $(n=5)$ territories. 


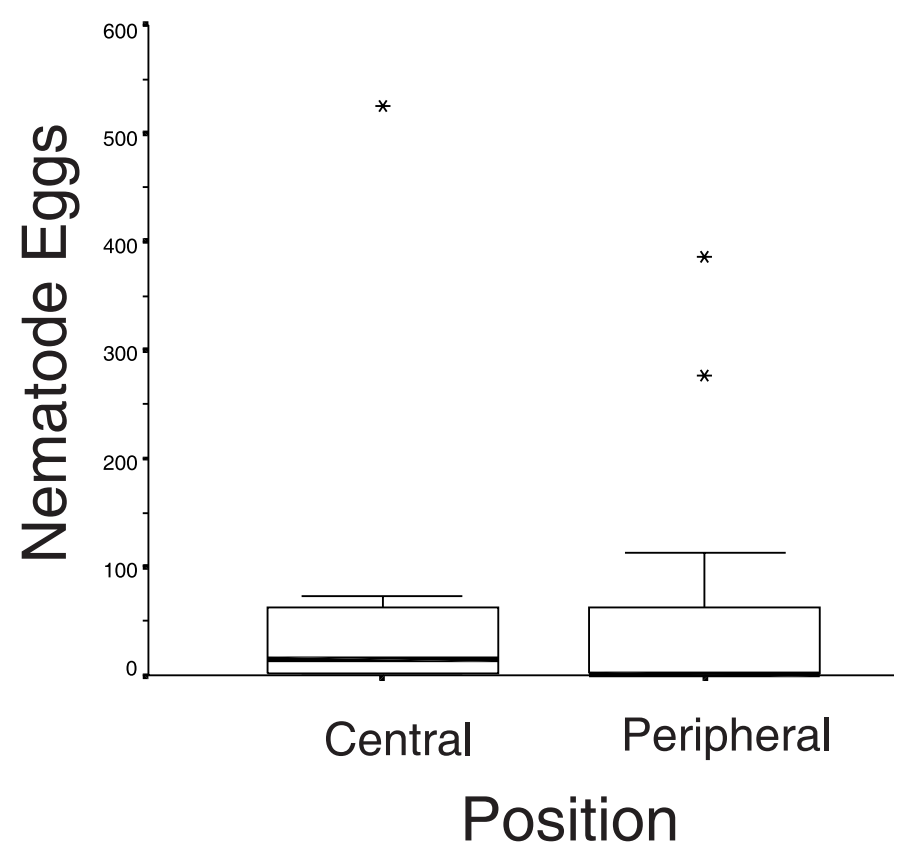

FIG. 1. Box-and-whisker plots of nematode egg loads for sharp-tailed grouse occupying central and peripheral territories on leks (* $=$ extreme outliers).

Nematode egg loads were not significantly smaller ( $p=0.08$; Fig. 1$)$ in central males $(\mathrm{n}=14)$ compared to peripheral individuals $(\mathrm{n}=12)$. In addition, nematode egg loads were not significantly different $(p=0.26$; Fig. 2$)$ between adult males $(n=19)$ and yearlings $(n=7)$. The frequency distribution for nematode egg data (Fig. 3) shows the characteristic "hollow" curve type, in which most hosts have few parasites and most parasites are on only a few hosts (Tsuji et al., 2001).

\section{DISCUSSION}

Hematozoa have been reported to occur in other subspecies of sharp-tailed grouse from North Dakota, USA (Wetmore, 1939), and Michigan, USA (Cowan and Peterle, 1957); however, none were found in the northern sharptailed grouse examined in this study. Indeed, a general lack of hematozoal parasites in avian species occupying the zone designated as the Arctic barrens has been reported in several studies (Laird, 1961; Bennett et al., 1992).

Coccidia have been reported in other subspecies of sharp-tailed grouse from Wisconsin, USA (e.g., Morgan and Hamerstrom, 1941), but none were found in the present study. The only indication of endoparasitic infection in the present study was the nematode eggs of an unknown species recovered from the intestinal tract. However, nematode egg load was not related to either territorial position or age of males, and most individuals had few endoparasites. Perhaps no differences in endoparasite loads were found among lekking sharp-tailed grouse because good health is necessary for them to establish and maintain territories on the lek (Kermott, 1982); that is, males maintaining

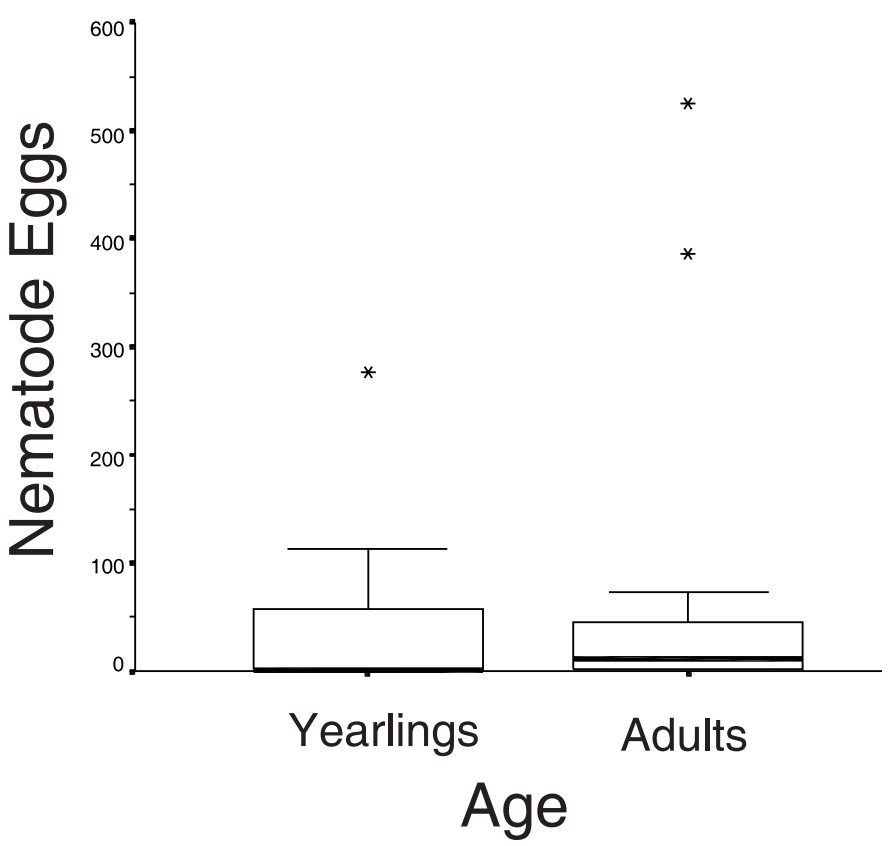

FIG. 2. Box-and-whisker plots of nematode egg loads for sharp-tailed grouse adults and yearlings occupying territories on leks $(*=$ extreme outliers).

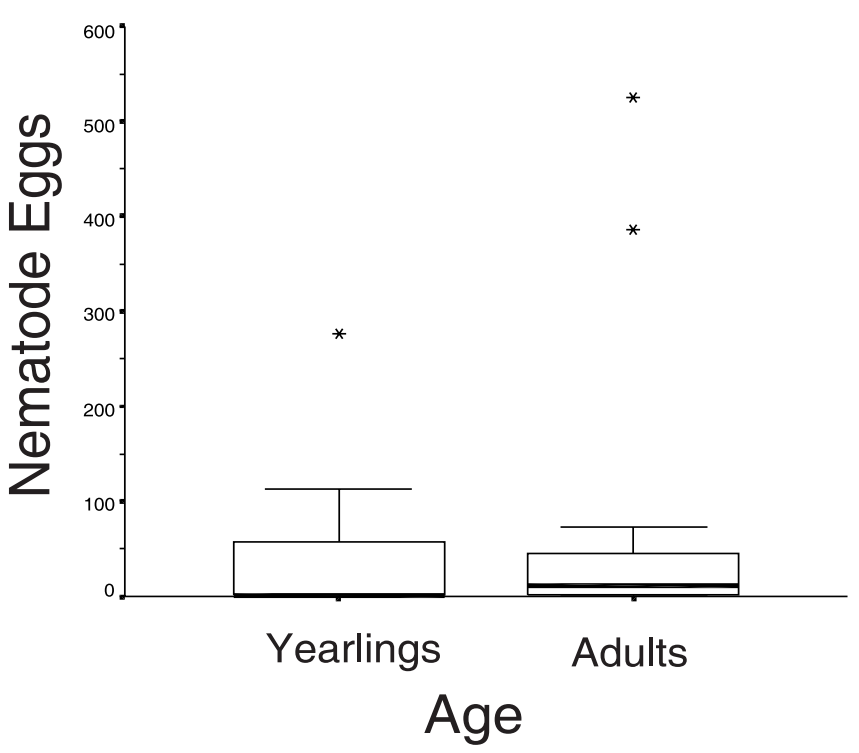

FIG. 3. Frequency distribution of nematode egg loads of lekking sharp-tailed grouse.

positions on leks may not be a random sample of males in populations. Indeed, unhealthy or injured male sharptailed grouse may be forced off the lek (Kermott, 1982). If this is so, then a female mating with a lekking male may be avoiding the less healthy males of the population by default.

This pilot study provides only a snapshot view of endoparasites in these northern sharp-tailed grouse, being limited to those present in males during the breeding season. However, we believe that future study of nematodes may provide insight into the population dynamics of 
this grouse subspecies. Indeed, nematode infection has been shown to be important to survivorship of other grouse species. In wild red grouse, Lagopus lagopus scoticus, Wilson (1983) reported that $90 \%$ of the birds examined carried the caecal threadworm Trichostrongylus tenuis, with old birds carrying 30 times the burden of the young (no age effects were seen in the present study). Predators preyed selectively on red grouse heavily infected with the caecal threadworm (Hudson et al., 1992a). In addition, winter and breeding losses have been shown to be positively correlated with the intensity of parasitic infection in these grouse (Hudson and Dobson, 1991; Hudson et al., 1992b). Hudson et al. (1992b) also demonstrated that female red grouse with increased caecal nematode burdens emitted a stronger scent and were consequently more vulnerable to mammalian predators. Allowing for the fact that nematodes have been shown to be important to the survivorship of red grouse, this bird species typically lives at higher densities $\left(<25 \mathrm{birds} / \mathrm{km}^{2}\right.$ at low levels to $>500$ birds $/ \mathrm{km}^{2}$ at high levels; Hudson and Dobson, 1991) than are typically associated with sharp-tailed grouse. However, the northern sharp-tailed grouse has been reported to go though population cycles during which numbers increased so dramatically over two- to three-year periods that mass southward emigrations of this species occurred (Snyder, 1935). In the best-documented case (in the scientific literature) of this type of mass emigration by the northern sharp-tailed grouse, it was reported that in the fall of 1932, small (4 sharp-tailed grouse) and large flocks (> 100) moved steadily through the Moosonee, Ontario, region (western James Bay) for approximately three consecutive weeks (Snyder, 1935). Moreover, there is a report of at least 50 dead northern sharp-tailed grouse seen on privately owned land (size dimensions of the land were not given) in Iroquois Falls, Ontario (Snyder, 1935). This level of mortality approaches that reported for red grouse during population peaks (Hudson and Dobson, 1991), assuming that the area in Iroquois Falls was approximately $1.5 \mathrm{~km}^{2}$. However, it should be noted that 11 postmortem examinations of northern sharp-tailed grouse shot during the 1932 emigration showed no parasitic worms, although an examination for nematode eggs was not conducted (Snyder, 1935). The importance of nematodes to the survivorship of northern sharp-tailed grouse is unknown. Future research may clarify matters.

\section{ACKNOWLEDGEMENTS}

We thank the First Nations people for allowing us to salvage grouse remains, J.D. Karagatzides for statistical and graphical assistance, B. Cardone for histological preparation, D. Brooks for methodological advice on nematodes, and especially R.I.C. Hansell, M. Sidall, and S. Desser for their help in the preservation, preparation, and identification of the parasites. Comments from anonymous reviewers were also appreciated.

\section{REFERENCES}

AMMANN, G.A. 1944. Determining the age of pinnated and sharptailed grouses. Auk 8:170-171.

BENNETT, G.F. 1970. Simple techniques for making avian blood smears. Canadian Journal of Zoology 48:585-586.

BENNETT, G.F., MONTGOMERIE, R., and SEUTIN, G. 1992. Scarcity of haematozoa in birds breeding on the arctic tundra of North America. Condor 94:289-292.

CHEN, G.J., and DESSER, S.S. 1989. The Coccidia (Apicomplexa: Eimeriidae) of frogs from Algonquin Park, with description of two new species. Canadian Journal of Zoology 67:1686-1689.

COWAN, A.B., and PETERLE, T.J. 1957. Leucocytozoon bonasae Clarke in Michigan sharp-tailed grouse. Journal of Wildlife Management 21:469-471.

FINLAND, M. 1973. Superinfections in the antibiotic era. Postgraduate Medicine 54:175-183.

GIBSON, R.M. 1990. Relationships between blood parasites, mating success and phenotypic cues in male sage grouse Centrocercus urophasianus. American Zoologist 30:271-278.

HANSON, H.C. 1953. Muskeg as sharp-tailed grouse habitat. Wilson Bulletin 65:235-241.

HOGLUND, J., ALATALO, R.V., and LUNDBERG, A. 1992. The effects of parasites on male ornaments and female choice in the lek-breeding black grouse (Tetrao tetrix). Behavioural Ecology and Sociobiology 30:71-76.

HUDSON, P.J., and DOBSON, A.P. 1991. The direct and indirect effects of the caecal nematode Trichostrongylus tenuis on red grouse. In: Loye, J.E., and Zuk, M., eds. Bird-parasite interactions. Oxford: Oxford University Press. 49-68.

HUDSON, P.J., DOBSON, A.P., and NEWBORN, D. 1992a. Do parasites make prey vulnerable to predation? Red grouse and parasites. Journal of Animal Ecology 61:681-692.

HUDSON, P.J., NEWBORN, D., and DOBSON, A.P. 1992b. Regulation and stability of a free-living host-parasite system: Trichostrongylus tenuis in red grouse. 1. Monitoring and parasite reduction experiments. Journal of Animal Ecology 61: 477-486.

HUPP, J.W., and BRAUN, C.E. 1989. Endogenous reserves of adult male sage grouse during courtship. Condor 91:266-271.

JOHNSON, L.L., and BOYCE, M.S. 1991. Female choice of males with low parasite loads in sage grouse. In: Loye, J.E., and Zuk, M., eds. Bird-parasite interactions. Oxford: Oxford University Press. 377-388.

KERMOTT, L.H. 1982. Breeding behavior in the sharp-tailed grouse. Ph.D. dissertation. University of Minnesota, St. Paul, Minnesota, U.S.A.

KHEYSIN, Y.M. 1972. Life cycle of Coccidia of domestic animals. Baltimore, Maryland: University Park Press.

KROGH, C.M.E. 1991. Compendium of pharmaceuticals and specialties. 26th ed. Ottawa: Canadian Pharmaceutical Association.

LAIRD, M. 1961. A lack of avian and mammalian haematozoa in the Antarctic and Canadian Arctic. Canadian Journal of Zoology 39:209-213.

LOEHLE, C. 1997. The pathogen transmission avoidance theory of sexual selection. Ecological Modelling 103:231-250. 
MORGAN, B.B., and HAMERSTROM, F.M. 1941. Notes on the endoparasites of Wisconsin pinnated and sharp-tailed grouse. Journal of Wildlife Management 5:194-198.

SLOSS, M.W. 1970. Veterinary clinical parasitology. Ames: Iowa State University Press.

SNYDER, L.L. 1935. A study of the sharp-tailed grouse. Biological Series No. 40. Toronto: University of Toronto Press.

SPURRIER, M.F., BOYCE, M.S., and MANLY, B.F.J. 1991. Effects of parasites on mate choice by captive sage grouse. In: Loye, J.E., and Zuk, M., eds. Bird-parasite interactions. Oxford: Oxford University Press. 389-398.
TSUJI, L.J.S., KOZLOVIC, D.R., SOKOLOWSKI, M.B., and HANSELL, R.I.C. 1994. Relationship of body size of male sharp-tailed grouse to location of individual territories on leks. Wilson Bulletin 106:329-337.

TSUJI, L.J.S., KARAGATZIDES, J.D., and DeIULIIS, G. 2001. Ectoparasites in lekking sharp-tailed grouse, Tympanuchus phasianellus. Canadian Field-Naturalist 115:210-213.

WETMORE, P.W. 1939. A species of plasmodium from the sharptailed grouse infective to other grouse. Journal of Wildlife Management 3:361-365.

WILSON, G.R. 1983. The prevalence of cecal threadworms (Trichostrongylus tenuis) in red grouse (Lagopus lagopus scoticus). Oecologia 58:265-268. 